\title{
Occupational exposure to asbestos as evaluated from work histories and analysis of lung tissues from patients with mesothelioma
}

\author{
Timo Tuomi, Matti S Huuskonen, Lauri Tammilehto, Esa Vanhala, Matti Virtamo
}

\begin{abstract}
The past occupational exposure to asbestos of 23 patients with mesothelioma ( 21 men and two women) has been evaluated by a personal interview of their work history and by determination of the fibre burden in their lung tissue with scanning electron microscopy (SEM) and $x$ ray microanalysis. According to the work history, nine patients $(39 \%)$ had definitely been or probably been exposed to asbestos, six patients $(26 \%)$ had had possible exposures, and eight patients (35\%) unlikely or unknown exposure to asbestos. The two female patients were in the unknown exposure category. The fibre concentrations in the patients' lung tissue ranged from less than $0 \cdot 1$ million to 370 million fibres ( $f$ ) per $g$ dry tissue. Concentrations of over one million $f$ per $g$ dry tissue were found in 15 patients $(65 \%)$. The lung fibre concentrations of all nine male office workers analysed for reference were less than one million $f$ per $g$ dry tissue. Seventy eight per cent of the patients with mesothelioma had at least possible exposure according to their history of work or concentrations of more than one million $f$ per $g$ dry tissue.
\end{abstract}

According to the Finnish Cancer Registry, 37 mesotheliomas were registered in Finland in 1986, 27 in men and 10 in women (L Teppo, Finnish Cancer Registry, personal communication). The annual incidence rate has doubled during the last 10 years, to 10 cases per million population. Mesothelioma has increasing social and economic importance as an occupational disease. Effective practical means are therefore needed to identify the patients' possible

Institute of Occupational Health, Helsinki, Finland T Tuomi, M S Huuskonen, E Vanhala, M Virtamo

Helsinki University Central Hospital, Department of Thoracic Medicine, Helsinki, Finland

L Tammilehto occupational exposure to asbestos. Evaluation of the patients' history of work is the primary step. A person's past exposure to asbestos, particularly the intensity, is, however, often difficult to assess even when a chronological history of work is available.

Analysis of the concentration of fibre in lung tissue provides data that help to estimate a person's past exposure to asbestos, and serve as a supplement to work and exposure history. ${ }^{1}$ Lung fibre analysis is based on the facts that asbestos fibres remain in the lungs and that their chemical composition does not alter significantly. Even exposure in childhood can be identified at an older age. ${ }^{2}$ Lung fibre analysis is especially useful in finding occult exposures, whether occupational or non-occupational. These situations do not necessarily register in the work history and are not comprehended by the patient, but can lead to a significant fibre burden in lung tissue. The mineralogical types of asbestos found in lung tissue can also provide information about the type and magnitude of exposure. The main limitations of the analysis of lung fibre burden are that the measured fibre concentration in lung tissue represents a lifelong retention of fibres, and thus recent exposures cannot be distinguished from past ones and the relative amounts of different types of fibre found in the lungs do not necessarily correspond to the person's exposures. This problem arises with chrysotile, which is known to be removed more effectively from the lungs than asbestiform amphiboles. Therefore a low concentration of chrysotile in the lungs does not necessarily imply the absence of past occupational exposure to chrysotile, which may in fact have caused the disease. ${ }^{3}$

The aim of our study was to compare history of work with the lung fibre counts in Finnish patients with mesothelioma and to shed light on their history of exposure to asbestos.

\section{Materials and methods} SUBJECTS

The 23 mesotheliomas were diagnosed at the $\mathrm{Hel}-$ sinki University Central Hospital between January 1985 and December 1988. During this period 48 new 
mesotheliomas were diagnosed in total. All patients, who could be interviewed and from whom a lung tissue sample was available, either from diagnostic surgery or at necropsy, were included. Their mean age at diagnosis was 56 (range 39-72 years). All mesotheliomas were histologically confirmed by a mesothelioma panel.

Samples of lung tissue from nine male office workers, on whom necropsies were carried out in 1984 at the Department of Forensic Medicine, Helsinki University, were analysed as a reference. These cases were selected from a study on sudden deaths in the male population. ${ }^{4}$ In this study, the relatives had been interviewed and asked to provide occupational information concerning the deceased patients. The mean age at death of this reference group was 53 (range 37-67 years).

\section{EVALUATION OF THE HISTORIES OF WORK}

The patients with mesothelioma were interviewed personally about their history of work, past occupational, domestic, and environmental exposure to asbestos, smoking habits, injuries, and earlier radiotherapy of the thorax. The interview was conducted during the patients' visits to the hospital or during their stay in hospital. Unaware of the results of the fibre analysis, a panel consisting of two occupational hygienists and an occupational physician then evaluated the probability of past exposure to asbestos. The panel classified the occupational exposure into four categories according to the guidelines:

Definite exposure (group I): patients employed in mining of asbestos, manufacture of asbestos products, the asbestos cement industry, asbestos insulation, or demolition of old buildings.

Probable exposure (group II): patients employed in shipyards, the construction industry, or metal workshops.

Possible exposure (group III): patients employed in various trades with exposure to dust such as mining, power plants, transportation, or the paper and pulp industry.

Unlikely or unknown exposure (group IV): patients employed in occupations with no evidence of exposure to asbestos.

An exposure time of one month was regarded as a minimum. ${ }^{5}$

\section{ANALYSIS OF FIBRE IN LUUNG TISSUE}

In five cases the samples were taken by thoracotomy. The other 18 cases had samples taken at necropsy when one sample of normal tissue was taken from the front side of the upper left lobe. Biopsy samples were taken similarly from healthy tissue. The samples taken from the office workers at necropsy were embedded in paraffin, which was subsequently dis- solved with xylene. A low temperature ashing technique was used to remove organic tissue. Fibres were counted with a JEOL 100 CX-ASID4D-electron microscope in SEM-mode. All inorganic particles which had a length to width ratio greater than 3 and roughly parallel sides were defined as fibres and counted. A magnification of 5000 was used in counting and one of up to 100000 in measuring the fibre dimensions directly from a screen. Fibres thinner than $0 \cdot 1 \mu \mathrm{m}$ could be detected with the $5000 \mathrm{mag}$ nification. ${ }^{6}$

An energy dispersive $x$ ray microanalyser (Tracor TN 5500) was used to determine the type of fibre. Fibres thicker than $0.5 \mu \mathrm{m}$ could be analysed to distinguish different types of asbestos. The intensity ratios of $\mathrm{Si}, \mathrm{Mg}, \mathrm{Fe}$, and $\mathrm{Na}$ were utilised in identification by comparing the peak ratios to standard spectra.

\section{Results}

EVALUATION OF EXPOSURE

Table 1 lists the occupations, the exposure classification, and the fibre concentrations of the patients with mesothelioma. The occupations are those in which exposure to asbestos had most likely occurred or those with the longest duration during life. In the evaluation of histories of work, the 23 patients were placed in four exposure groups: two patients $(9 \%)$ in group I, seven patients $(30 \%)$ in group II, six patients $(26 \%)$ in group III, and eight patients $(35 \%)$ in group IV.

The first two groups (definite and probable exposure) contained $39 \%$ of the patients. The two patients in group I had been employed in shipbuilding. Both stated explicitly that they had worked with asbestos or had been exposed at work. Four of the seven patients in group II had worked as an electrician, a spray painter, a welder, and a plumber in the shipyard. One patient in group II had worked in the construction industry, one as a serviceman in a power plant, and one as a foundryman and tram repairman. Six patients $(26 \%)$ were exposed to asbestos in shipbuilding and represent all the largest occupational groups in shipyards. Two of the six patients in group III had worked in the construction industry in occupations with apparently low probability of exposure to asbestos. The other four patients were assessed to have been possibly exposed to asbestos at work in electrical installations, in a power plant, in truck and engine repair, or in a rubber factory.

The mean period between the start of exposure and the year of diagnosis (latency) was 35 years (range 2155 years). The mean duration of the exposure, calculated as the sum of work periods in occupations with exposure to asbestos, was 23 years (range 7-39 years). 
Table 1 Data on exposure and lung fibre concentrations in 23 patients with mesothelioma

\begin{tabular}{|c|c|c|c|c|c|}
\hline \multirow[b]{2}{*}{ Age and sex } & \multirow[b]{2}{*}{ Occupation } & \multirow[b]{2}{*}{ Exposure group } & \multicolumn{2}{|c|}{ Asbestos exposure } & \multirow{2}{*}{$\begin{array}{l}\text { Fibre concentration } \\
\text { in lung (million f/g } \\
\text { dry tissue) }\end{array}$} \\
\hline & & & duration (y) & latency $(y)$ & \\
\hline $59 / M$ & Electrician, shipyard & I & 21 & 30 & 370 \\
\hline $39 / \mathrm{M}$ & Insulator, shipyard & I & 20 & 21 & 88 \\
\hline $54 / \mathrm{M}$ & Electrician, shipyard & II & 37 & 39 & 160 \\
\hline $46 / M$ & Painter, shipyard & II & 9 & 27 & 76 \\
\hline $47 / M$ & Welder, shipyard & II & 21 & 21 & 26 \\
\hline $72 / \mathrm{M}$ & Construction worker & II & 37 & 47 & 21 \\
\hline $71 / \mathrm{M}$ & Construction, shipyard & II & 28 & 49 & 17 \\
\hline $55 / \mathrm{M}$ & Serviceman, power plant & II & 38 & 38 & 11 \\
\hline $59 / \mathrm{M}$ & Foundryman, tram repair & II & 39 & 44 & $5 \cdot 5$ \\
\hline $41 / M$ & Construction, ship's crew & III & 10 & 24 & 11 \\
\hline $52 / \mathrm{M}$ & Construction worker & III & 25 & 35 & $3 \cdot 1$ \\
\hline $71 / \mathrm{M}$ & Electrician & III & 7 & 55 & $1 \cdot 2$ \\
\hline $63 / \mathrm{M}$ & Turner, power plant & III & 23 & 27 & $0 . \overline{5}$ \\
\hline $56 / M$ & Truck driver, engine repair & III & 20 & 33 & 0.2 \\
\hline $63 / \mathrm{M}$ & Rubber worker & III & 14 & 34 & $<0 \cdot 1$ \\
\hline $52 / \mathrm{M}$ & Caretaker, truck driver & IV & - & - & 13 \\
\hline $54 / \mathrm{M}$ & Gardener & IV & - & - & $6 \cdot 2$ \\
\hline $70 / \mathrm{M}$ & Salesman, hardware & IV & - & - & $1 \cdot 2$ \\
\hline $65 / M$ & Electrical engineer & IV & - & - & 0.8 \\
\hline $50 / \mathrm{M}$ & Ship's crew, truck driver & IV & - & - & 0.5 \\
\hline $43 / W$ & Seamstress & IV & - & - & 0.4 \\
\hline $60 / M$ & Editor & IV & - & - & $0 \cdot 2$ \\
\hline $57 / \mathrm{W}$ & Teacher & IV & - & - & $0 \cdot \overline{1}$ \\
\hline
\end{tabular}

$\mathrm{M}=\mathrm{Man} ; \mathrm{W}=$ woman.

The remaining eight patients were evaluated not to have had occupational contact with asbestos that could have led to substantial exposure to airborne fibres. The two women were classified into this group. One of them had worked as a seamstress and the other as a teacher. Three of the six men, two truck drivers and an electrical engineer, had worked in occupations in which exposure to asbestos could potentially take place but, according to their own description of past jobs, they were classified into group IV. No exposure to asbestos was assessed to have taken place in the occupations of the remaining three patients in group IV-namely, a gardener, a hardware salesman, and a newspaper editor.

\section{CONCENTRATIONS OF FIBRE IN LUNG TISSUE}

The concentrations of fibre in lung tissue from the patients with mesothelioma ranged from less than $0 \cdot 1$ million to 370 million fibres ( $f$ ) per $g$ dry tissue. Concentrations of more than one million $f$ per $g$ dry tissue were found in 15 patients $(65 \%)$ and more than 10 million $\mathrm{f}$ per $\mathrm{g}$ dry tissue in 10 patients $(43 \%)$. The highest values, more than 100 million $f$ per $g$ dry tissue, were in two shipyard electricians. Asbestos fibres (amosite, anthophyllite, crocidolite, or tremolite) were found in 21 patients. In six patients $(26 \%)$ crocidolite and amosite were the main types of fibre. In eight patients (35\%) anthophyllite was the main type and in seven patients $(30 \%)$ both crocidolite/amosite and anthophyllite dominated. In one patient no fibres were found, and in one only silicate fibres were detected. No manmade minerals such as glass fibres were found. Table 2 lists the concentrations of fibre for the office workers. These ranged from less than $0 \cdot 1$ to 0.6 million $f$ per $g$ dry tissue.

\section{LUNG FIBRE BURDEN IN THE FOUR EXPOSURE GROUPS}

The figure shows the relation between the probability of exposure evaluated from histories of work and the measured fibre burden in lung tissue. The concentrations of fibre are arranged in four groups by the probability assessed from the history of work. Patients with a higher probability of exposure tended to have higher concentrations of fibre. In exposure groups I and II (definite and probable exposure) all nine patients had concentrations of fibre of more than one million $f$ per $g$ dry tissue. In exposure groups I, II, and III taken together, 12 patients out of $15(80 \%)$ had concentrations of more than one million $f$ per $g$ dry tissue. In group III three out of six patients $(50 \%)$ ) and in group IV three out of eight patients $(38 \%)$ had concentrations of fibre greater than one million $f$ per $g$ dry tissue. In total $78 \%$ of the patients had at least possible exposure according to their history of work or lung fibre concentration greater than one million $f$ per $g$ dry tissue.

\section{Discussion}

Based on the histories of work, $65 \%$ of the patients with mesothelioma were assessed to have definite, probable, or possible past exposure to asbestos. For the men the proportion was $71 \%$. We evaluated the histories of work from the information given by the patients at interview, which is undoubtedly the best 
Table 2 Characteristics and lung fibre concentrations of nine male office workers

\begin{tabular}{llll}
\hline Age & Occupation & Cause of death & $\begin{array}{c}\text { Fibre concentration in lung (millionf } \\
\text { per } g \text { dry tissue) }\end{array}$ \\
\hline 62 & & Myocardial infarction & $0 \cdot 3$ \\
46 & Clerk & Myocardial infarction & $0 \cdot 5$ \\
51 & Policeman & Alcohol intoxication & $0 \cdot 6$ \\
46 & Post clerk & Suicide & $0 \cdot 2$ \\
67 & Clerk & Myocardial infarction & $0 \cdot 6$ \\
41 & Clerk & Suicide & $0 \cdot 4$ \\
37 & Bank clerk & Myocardial infarction & $<0 \cdot 1$ \\
64 & Industrial clerk & Lung embolism & $<0 \cdot 1$ \\
66 & Clerk & Cerebral haemorrhage & $0 \cdot 1$ \\
\hline
\end{tabular}

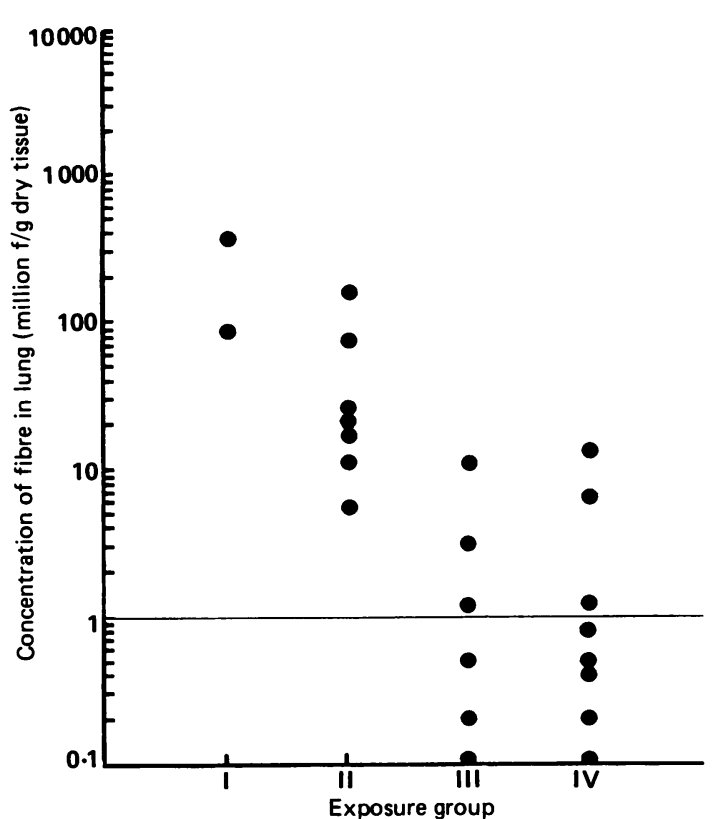

Concentrations of fibres in lungs and exposure grouping of 23 patients with mesothelioma.

method. With few exceptions there was a good coherence between the probabilities of exposure and the measured fibre burden in the lungs of the patients. In general, the patients with a high probability of exposure had higher concentrations of lung fibre.

We reported recently the concentrations of fibre in lung tissue of 19 men with mesothelioma and 15 referents and concluded that a concentration of more than one to two million $\mathrm{f}$ per $\mathrm{g}$ dry tissue as measured by scanning electron microscopy indicates occupational exposure to asbestos. ${ }^{6}$ In $79 \%$ of the patients with mesothelioma and in $20 \%$ of the male referents who had died from causes not related to exposure to asbestos, we measured fibre concentrations of more than one million $\mathrm{f}$ per $\mathrm{g}$ dry tissue. For the present 23 patients with mesothelioma, which include 17 patients reported earlier, ${ }^{6}$ the correspond- ing value was $65 \%$. In the office workers all lung fibre concentrations were less than one million $f$ per $g$ dry tissue.

According to the best available information and the criteria that there was at least possible history of occupational exposure, or a concentration of fibre of more than one million $\mathrm{f}$ per $\mathrm{g}$ dry tissue, $\mathbf{7 8 \%}$ of the patients with mesothelioma had been exposed to asbestos at work.

No occupational exposure to asbestos was found for the two women; they had worked outside the home and their concentrations of fibre were consistently less than one million $f$ per $g$ dry lung tissue. Asbestos fibres, either anthophyllite or tremolite, were, however, found in their lungs. A probable nonoccupational source of exposure could be the common practice of families in Finland to build their own houses. Asbestos was previously used for insulation of pipes and asbestos cement products were used in construction.

The concentration of fibre in three patients in exposure group IV exceeded one million $f$ per $g$ dry tissue. Their history of work showed no contacts with asbestos that could have led to exposure to airborne fibres. After combining the data from the fibre analysis and interviews, we examined the backgrounds of these contradictory findings more closely. The high fibre burden of the three patients was apparently due to normal but not typical work tasks. The caretaker had probably been exposed to asbestos during maintenance work in a central heating room where the ceilings had been sprayed with asbestos; the gardener had been exposed during the construction of greenhouses with insulation material containing asbestos on the pipelines. The types of asbestos found in their lungs (crocidolite in the caretaker and anthophyllite in the gardener) were consistent with the suspected conditions of exposure. The third patient had worked in hardware stores and was probably exposed when handling, cutting, and packing various building materials. There are reported cases of mesothelioma with unlikely occupational exposure to asbestos. ${ }^{7}$ These three cases emphasise caution when judging that a person has not been occupationally exposed to asbestos. 
Four construction workers were present among the patients with mesothelioma. One of them had also worked as a plumber in shipbuilding. For him, and one other worker, the exposure to asbestos was assessed to be at least probable. For the two other construction workers exposure was regarded as possible, but the probability was low. They nevertheless had high concentrations of fibres in their lungs. One of the men had also worked as crew on a ship for 10 years, which could account for his exposure. Also the electrician in exposure group III, who had performed electrical installations in a factory, had a concentration of fibre that indicated occupational exposure. Electricians commonly handle asbestos insulations, especially in older buildings and factories, and drill holes in asbestos cement boards, which, in this case, had apparently caused a significant fibre burden. Exposure to asbestos has been common among construction workers in Finland. ${ }^{8}$

The use of lung fibre analysis led to a better assessment of past exposure to asbestos in the six patients described. It identified three further exposed cases, and the exposure of three others could be confirmed. The experience from this study supports the view that a positive result in lung fibre analysis provides sufficient evidence of exposure to asbestos, despite a negative or uninformative history of work. We did not find any cases where environmental or domestic exposure would have caused concentration of fibre in the lungs of more than one million $\mathrm{f}$ per $\mathrm{g}$ dry tissue.

The low concentrations of fibre found in the lungs of some patients with mesothelioma overlap with the results obtained from the general population. ${ }^{7910}$ The causal significance of a low concentration cannot be evaluated in individual cases of mesothelioma; for medicolegal purposes these cases have to be regarded as exposed to asbestos in case of positive history of work; a history of work strongly indicating exposure to asbestos dust cannot be overruled by a negative lung fibre analysis. ${ }^{11}$

Present knowledge provides no basis to establish a certain lower limit of lung fibre burden that would exclude occupational exposure or the aetiological role of asbestos in individual cases of mesothelioma.
Nevertheless, it is possible to establish practical limits which can be regarded as an indication of occupational exposure to asbestos.

We express our sincere thanks to Mrs R VesantoPaavola who interviewed the patients, $P$ Karhunen $M D$, who helped in obtaining the tissue material, $A$ Karjalainen $\mathrm{MD}$, who analysed the necropsy samples, and T Kaustia MA who did the linguistic revision of the manuscript. The study was supported by the Finnish Work Environment Fund.

Requests for reprints to: Timo Tuomi, Institute of Occupational Health, Topeliuksenkatu 41 a A, SF00250 Helsinki, Finland.

1 McDonald AD, McDonald JC. Epidemiology of malignant mesothelioma. In: Antman K, Aisner J, eds: Asbestos related malignancy. Boston: Grune and Stratton, 1987:31-55.

2 Magee P, Wright JL, Chan N, Lawson L, Churg A. Malignant mesothelioma caused by childhood exposure to long fiber low aspect ratio tremolite. Am J Ind Med 1986;9:529-33.

3 Churg A. Chrysotile, tremolite and malignant mesothelioma in man. Chest 1988;93:621-8.

4 Penttilä A, Karhunen PJ. Alkoholverbrauch bei Männern mit plötzlichem unerwartetem Tod in Helsinki. Beitr Gerichtl Med 1989;47:361-8.

5 Mowé G, Gylseth B, Hartveit F, Skaug V. Fiber concentration in lung tissue of patients with malignant mesothelioma. Cancer 1985;56:1089-93.

6 Tuomi T, Segerberg-Konttinen M, Tammilehto L, Tossavainen A, Vanhala E. Mineral fiber concentration in lung tissue of mesothelioma patients in Finland. Am J Ind Med 1989;16:247-54.

7 Hirsch A, Brochard B, De Cremoux H, et al. Features of asbestos-exposed and unexposed mesothelioma. Am J Ind Med 1982;3:413-22.

8 Roto P, Oksu P, Rinne J-P, et al. Occurrence of asbestos related findings among Finnish construction workers. In: 23 rd International congress on occupational health, Montreal, Canada: 1990. (Book of abstracts 694).

9 Churg A, Wiggs B. Fiber size and number in workers exposed to processed chrysotile asbestos, chrysotile miners and the general population. Am J Ind Med 1986;9:143-52.

10 Mowé G, Gylseth B, Hartveit F, Skaug V. Occupational asbestos exposure, lung fiber concentration and latency time in malignant mesothelioma. Scand J Work Environ Health 1984 10:293-8.

11 Woitowitz H-J, Rödelsperger K, Manke J, Brückel. Identification and quantification of asbestos and other mineral fibres in human lung tissue with analytical scanning electron microscopy (STEM). Schriftenreihe der Bundesanstalt für Arbeitsshutz, Sonderschrift 27, Dortmund: Bundesanstalt für Arbeitsshutz, 1988. (Final report of project No. ENV-684-D of the Commission of the European Community.)

Accepted 23 July 1990 